\title{
A new, most likely unusual approach is crucial and upcoming for the use of stem cells in regenerative medicine
}

\author{
Virginia Tirino and Gianpaolo Papaccio* \\ Tissue Engineering and Regenerative Medicine Laboratory, Department of Experimental Medicine, Second University of Naples, Naples, Italy \\ *Correspondence: gianpaolo.papaccio@unina2.it
}

To date many articles and reviews have been devoted to the use of stem cells in regenerative medicine. Of the previous, some articles, about $20 \%$, are interesting and constitute an advance in knowledge, the majority $(50 \%)$ are of marginal interest, and some (30\%) are completely not useful, although they can be found in literature.

The emerging major problems affecting the impact of this field in patient's cure can be mainly found in the high costs of procedures and in other problems that need to be fully addressed by the scientific community, that we evidence below.

The following major questions must be still addressed for a true enhancement of the practical use of stem cells in patient's cure:

(1) New methods for GMP stem cell cultures, dedicated to grafts, must be used, including, for instance, microgravity, omega3 fatty acids, new oxygen bioreactors; this is a major point, of interest and that can be addressed by both biologists, physicians, and engineers;

(2) Ascertain genetic stability of stem cells before and after grafting is another key step. A schedule should be delivered and published on this issue by researchers, often after having obtained data of graft trials;

(3) The problem of quality and quantity of cells must be unambiguous and a general rule established. Many researchers try to demonstrate the purity of stem cell populations and try to obtain a translation of their findings. This point presents several ambiguities, mainly residing in the purity judgment itself;

(4) Interactions with already existing cancer stem cells in patients to be grafted is another great problem to be discussed and rules needed. Niches of cancer cells may already reside in the patient where a stem cell graft has been prepared and performed. This can be a serious problem depending on the response of stem cells to cancer because opposite opinions and effects exist at present on this topic;

(5) Cell selection, as well as GMP procedures, must be deeply discussed. The search of a high purity and selection decreases the quantity of stem cells and their effectiveness; GMP procedures are difficult to be followed, their costs are too high and cannot be supported by a large patient number (d'Aquino et al., 2009). Bureaucracy procedures, not only in Europe, are long, difficult, often require to "de novo" design the graft design and are required for each protocol and often the trials cannot be done.

Therefore, is it possible to have a new, different, and provocative approach? Can we answer to the following questions?

(a) How is possible to perfectly measure and standardize quality and quantity of stem cells? Are we sure that we are in search of such a purity (Tirino et al., 2011)?

(b) A "full" characterization and selection of stem cell populations decreases their quantity and/or potentials: is this necessary or needed all the time?

(c) How is possible to overcome the high costs of GMP procedures and reach the goal of a large-scale use of stem cells?

(d) Do stem cells can be still studied and used as components of a whole tissue/ organ (house to build) or as a vehicle of molecules and as a terrific recruitment for other cells?

(e) It would be possible and more "natural" to follow and recapitulate the embryonic development and physiological tissue repair processes (mainly niches for bone); (f) It would be more easy and effective to activate inflammation or other mechanisms for endogenous stem cell recruitment and proliferation. In other terms, should we stimulate the physiological role of endogenous stem cells instead of their grafting?

(g) The research of "ideal" stem cells, with a full and standardized characterization/selection is difficult to be followed and requires high costs that cannot be supported, using the actual technology. Can we overcome this step?

In our opinion researchers must change their traditional approaches if the goal of a large-scale use of stem cells is compulsory.

This does not imply that basic studies on biology of stem cells must not be done: they should continue, independently from the practical use of stem cells, which, on the other hand, cannot wait for more.

Moreover, the studies on non-human stem cells (i.e. rat, mice, and other animals) must be reduced to the minimum, this because those cells show many differences with human stem cells and we need to study more human stem cells.

We are sure that our goal are patients, while several animal stem cells features or proteins or other features cannot be found in human stem cells.

In summary, a great effort must be tried in order to avoid that we will acquire a lot of knowledge but no translation of studies in patients will be performed.

The latter would really be a great failure or "default."

\section{REFERENCES}

d'Aquino, R., De Rosa, A., Lanza, V., Tirino, V., Laino, L., Graziano, A., Desiderio, V., Laino, G., and Papaccio, G. (2009). Human mandible bone defect repair by the grafting of dental pulp stem/progenitor cells and collagen sponge biocomplexes. Eur. Cell. Mater. 18, 75-83.

Tirino, V., Paino, F., d'Aquino, R., Desiderio, V., De Rosa, A., and Papaccio, G. (2011). Methods for the 
identification, characterization and banking of human DPSCs: current strategies and perspectives. Stem Cell. Rev. 7, 608-615.

Received: 03 November 2011; accepted: 16 December 2011; published online: 05 January 2012.
Citation: Tirino V and Papaccio G (2012) A new, most likely unusual approach is crucial and upcoming for the use of stem cells in regenerative medicine. Front. Physio. 2:119. doi: 10.3389/fphys.2011.00119

This article was submitted to Frontiers in Craniofacial Biology, a specialty of Frontiers in Physiology.
Copyright (C) 2012 Tirino and Papaccio. This is an openaccess article distributed under the terms of the Creative Commons Attribution Non Commercial License, which permits non-commercial use, distribution, and reproduction in other forums, provided the original authors and source are credited. 